\title{
MAGDALENA MUSIAŁ-KARG
}

Poznań

\section{Instytucje demokracji bezpośredniej w procesie integracji europejskiej - od referendum ogólnonarodowego do europejskiej inicjatywy obywatelskiej}

Idea udziału obywateli w procesie podejmowania decyzji państwowych stanowi istotną część historii europejskiej. To właśnie realizując zasadę zwierzchnictwa narodu (urzeczywistniającą się w tym, że prawo powinno wyrażać wolę ogółu obywateli) uprawnieni obywatele mają możliwość wyrażania swojej woli w drodze instytucji demokracji bezpośredniej i demokracji przedstawicielskiej (za pośrednictwem wybranych uprzednio reprezentantów).

Motywacją do zajęcia się zagadnieniem wykorzystania instytucji demokracji bezpośredniej w procesie integracji europejskiej okazał się przede wszystkim fakt, iż państwa europejskie w ostatnich latach coraz częściej odwołują się do rozwiązywania wielu problemów związanych z funkcjonowaniem Unii Europejskiej właśnie w drodze referendum. Dodatkowo, w ostatnich latach - szczególnie w okresie związanym z procesem ratyfikowania Traktatu ustanawiajacego Konstytucję dla Europy oraz w następstwie jego niepowodzenia - przygotowania nowego Traktatu z Lizbony - pojawiła się na forum UE dyskusja na temat znalezienia wspólnej dla wszystkich państw członkowskich formuły przyjmowania istotnych rozwiązań unijnych. Po pojawiających się dyskusjach na temat m.in. transeuropejskiego referendum, przyjęto ostatecznie inne rozwiązanie demokracji bezpośredniej - europejską inicjatywę obywatelską.

Warto nadmienić, iż obserwowany w ostatnich kilkudziesięciu latach wzrost zainteresowania wykorzystaniem instytucji referendum w państwach europejskich wynika przede wszystkim z natury przemian politycznych, jakie miały i mają nadal miejsce w państwach starego kontynentu (największe znaczenie mają tu zapewne procesy transformacyjne w wielu państwach byłego tzw. bloku wschodniego). Doniosłym jest przy tym fakt, że większe niż wcześniej zainteresowanie bezpośrednimi formami demokratycznymi odnotować można zarówno w państwach zachodnioeuropejskich, jak i w Europie Środkowej i Wschodniej. Niejako płaszczyzną wspólną obu grup państw europejskich z perspektywy wykorzystania instytucji demokracji bezpośredniej jest proces integracji europejskiej, który to w różnych kontekstach był i jest przedmiotem wielu referendów przeprowadzonych w państwach członkowskich UE, jak i tych które nie należą do Unii, ale utrzymują z nią stosunki na różnych płaszczyznach.

Co więcej, w obliczu powiększającej się o kolejne państwa członkowskie Unii Europejskiej oraz pogłębiającej się integracji, niewątpliwie jednym z najważniejszych problemów staje się dziś kwestia unijnej demokracji, jednak rozpatrywanej nie z punktu widzenia pojedynczego państwa członkowskiego, ale przede wszystkim z perspektywy Unii Europejskiej - jako całości. 
Ponadto, zauważyć warto, że obecnie w związku z kryzysem finansowym, który dotknął nie tylko Europę jako kontynent, ale przede wszystkim Unię Europejską (a precyzyjniej tzw. strefę euro) istnieje pewne zagrożenie związane z wykorzystaniem referendum w celu rozstrzygania problemów natury europejskiej. Mowa tu o sytuacjach, kiedy rządzący w poszczególnych państwach członkowskich UE, chcąc zdjąć z siebie odpowiedzialność podejmowania trudnych decyzji np. finansowych, przedkładaliby bardzo skomplikowane kwestie do rozstrzygnięcia wyborcom (przykład Grecji, gdzie w listopadzie $2011 \mathrm{r}$. planowano przeprowadzić referendum w sprawie nowego pakietu ratunkowego dla kraju ${ }^{1}$. W głosowaniu Grecy mieliby sami zdecydować, czy chcą kolejnych cięć w związku z międzynarodową pomocą. Z referendum jednak zrezygnowano pod ogromną presją społeczną i unijną).

Instytucje demokracji bezpośredniej stanowią zatem niezwykle interesujący temat nie tylko ze względu na to, że liczba głosowań szczególnie w ostatnim dziesięcioleciu była bardzo wysoka (w stosunku do trzech poprzednich dekad charakteryzujących się przekazywaniem szeroko rozumianych spraw europejskich do rozstrzygnięcia wyborcom), ale także z racji tego, że państwa członkowskie UE, zdając sobie sprawę ze znaczenia zaangażowania obywateli w proces integracji europejskiej, postanowiły umieścić w Traktacie z Lizbony odpowiednie zapisy umożliwiające uprawnionym wpływ na decyzje polityczne w drodze europejskiej inicjatywy obywatelskiej²

Zamierzeniem tekstu jest zatem odpowiedź na pytanie o rolę demokracji bezpośredniej i jej instytucji w procesie integracji europejskiej, a także o perspektywy dalszego wykorzystania narzędzi bezpośredniej formy sprawowania rządów w procesie pogłębiania i poszerzania integracji w Europie. Aby zrealizować niniejsze zamierzenia postanowiono niniejsze rozważania podzielić na trzy główne części: pierwszą - najbardziej obszerną dotyczącą doświadczeń referendalnych związanych z procesem integracji europejskiej, drugą - zawierającą kilka uwag na temat propozycji wprowadzenia do porządku prawnego UE instytucji paneuropejskiego referendum oraz trzecią - dotyczącą najmłodszej formy demokracji bezpośredniej funkcjonujących na szczeblu unijnym - europejskiej inicjatywy obywatelskiej.

\section{Referenda w sprawach integracji europejskiej}

W szerokim wachlarzu form demokracji bezpośredniej (inicjatywa powszechna, referendum, plebiscyt, recall, zgromadzenie narodowe) referendum wydaje się instytucją najbardziej powszechną w procesie podejmowania decyzji państwowych przez suwerena. Głosowanie referendalne stało się jedną z ważnych form uzupełniających rządy przedstawicielskie w Europie. W większości państw europejskich referendum stanowi narzędzie stosunkowo często wykorzystywane w rozstrzyganiu spraw o charakterze narodowym. Szeroki wachlarz problemów, jakie można rozstrzygnąć odwołując się do

\footnotetext{
1 Grecja: będzie referendum w sprawie pakietu pomocowego, 31.10.2011, „Wprost.pl”, http://www.wprost.pl/ar/268087/Grecja-bedzie-referendum-w-sprawie-pakietu-pomocowego/, 11.10.2012.

2 Należy nadmienić, iż takie zapisy znalazły się również w Traktacie ustanawiajacym Konstytucję dla Europy - art. I-47, ust. 4.
} 
referendum, jest powodem coraz większego zainteresowania tą formą demokracji bezpośredniej. Wpływa na to również fakt, iż $\mathrm{w}$ ostatnich latach referendum odgrywa istotną rolę jako narzędzie podejmowania decyzji politycznych związanych z integracją europejską.

Pierwsze ożywienie w wykorzystaniu referendów w Europie - można rzec pierwsza fala referendalna - miała miejsce po II wojnie światowej, kiedy głównie w państwach zachodnioeuropejskich zwiększyła się liczba głosowań oraz różnorodność kwestii przedkładanych wyborcom do rozstrzygnięcia. Drugie ożywienie (druga fala referendalna) związane było z zachodzącymi w Europie Środkowej i Wschodniej procesami transformacyjnymi z początku lat 90 -tych XX stulecia. Odwoływanie się do decyzji suwerena w sprawach ogłoszenia niepodległości, w kwestiach prywatyzacji (będącej wynikiem procesów demokratyzacyjnych), czy wyrażanie zgody na obowiązywanie nowych konstytucji państwowych jeszcze bardziej wpłynęło na wzrost zainteresowania referendami. Minione czterdzieści lat są niezbitym dowodem na to, że do istotnego zwiększenia liczby głosowań referendalnych w Europie znacznie przyczyniła się także integracja europejska, który to proces spowodował kolejne ożywienie w wykorzystaniu demokracji bezpośredniej.

Proces integracji europejskiej jest tym, co wydaje się łączyć państwa obu części Europy pod względem odwoływania się do narzędzi demokracji bezpośredniej - szczególnie do instytucji referendum ogólnonarodowego. Zarówno państwa zachodnioeuropejskie, jak i te z Europy Środkowej i Wschodniej zaczęły bowiem wykorzystywać referenda w większym niż wcześniej zakresie, co miało bezpośredni związek np. z kandydowaniem poszczególnych państw do UE, z członkostwem w UE, ze stosunkami tzw. państw trzecich (nienależących do struktur unijnych) z Unią, czy też z pogłębiającymi się stale procesami integracyjnymi. Godzi się zauważyć, iż czasami referendum ogólnonarodowe jest narzędziem, do którego odwołują się rządy państw w obliczu różnego rodzaju kryzysów. Za przykład może posłużyć wspomniana już Grecja, a także Wielka Brytania (referendum w sprawie dalszego członkostwa we Wspólnocie Europejskiej z 1975 r., plany referendum w sprawie zrezygnowania z członkostwa w UE zapowiadane przez premiera Camerona m.in. w lipcu 2012 r. ${ }^{3}$ ). Stwierdzić można zatem, iż różnego rodzaju zagadnienia związane z procesem integracji europejskiej i z samą Unią zdominowały $\mathrm{w}$ ostatnich latach zakres przedmiotowy referendów praktycznie na całym kontynencie europejskim, zarówno w państwach należących do UE, jak i tych niebędących jej członkami.

Za pośrednictwem demokracji bezpośredniej państwa członkowskie Unii, bądź też państwa związane z nią różnego rodzaju relacjami i zależnościami, kształtowały struktury zjednoczonej Europy oraz stosunki pomiędzy państwami ją tworzącymi, a także relacje między UE a państwami trzecimi. Na przełomie ostatnich 40-tu lat (w okresie 1972-2012) przeprowadzono 53 ogólnonarodowe referenda w sprawach dotyczących procesów integracyjnych w Europie. W ciągu tego okresu większość państw należących obecnie do UE, przeprowadziła przynajmniej jedno głosowanie związane z procesami integracji europejskiej. Wszystkie dotychczasowe referenda

${ }^{3}$ N. Watt, David Cameron says Britain will get vote on leaving EU, but not yet, 2.07.2012, ,The Guardian", http://www.guardian.co.uk/politics/2012/jul/02/david-cameron-europe-referendum, 17.10.2012. 
europejskie $^{4}$ były głosowaniami państwowymi - mimo że ich rezultat przekładał się często w dużym zakresie na kwestie o charakterze ponadnarodowym (np. irlandzkie głosowania nad traktatem z Nicei, zakończone negatywną odpowiedzią francuskie i holenderskie referenda w sprawie ratyfikacji Traktatu ustanawiajacego Konstytucje dla Europy i in.).

Na uwagę zasługuje fakt, iż przeprowadzone do tej pory referenda europejskie dowodzą wielości i różnorodności spraw, które rozstrzygane były w głosowaniach referendalnych. Ponadto wskazują, iż stosunkowo często odwoływano się do tego sposobu przy podejmowaniu decyzji o charakterze europejskim w poszczególnych państwach ${ }^{5}$. Biorąc pod uwagę fakt, że żadna sprawa na świecie nie była przedmiotem tak dużej liczby głosowań powszechnych w tak wielu państwach, stwierdzić należy, iż Europa odgrywa w tym względzie pionierską rolę.

W tabeli 1 przedstawione zostały wszystkie narodowe (ale także regionalne ${ }^{6}$ ) referenda związane z kwestią integracji europejskiej. Uwzględnione w tabeli głosowania przeprowadzane były zarówno w państwach członkowskich, państwach kandydujących oraz w państwach trzecich.

Tabela 1

Referenda w sprawach integracji europejskiej

\begin{tabular}{|r|l|c|l|c|c||}
\hline L.p. & \multicolumn{1}{|c|}{ Państwo } & Data & \multicolumn{1}{|c|}{ Przedmiot } & $\begin{array}{c}\text { Frekwencja } \\
\mathbf{( \% )}\end{array}$ & $\begin{array}{c}\text { Tak } \\
\text { (\%) }\end{array}$ \\
\hline 1 & \multicolumn{1}{|c|}{2} & 3 & 4 & 5 & 6 \\
\hline 1 & Francja & 23.04 .1972 & rozszerzenie WE & 60,27 & 68,28 \\
\hline 2 & Irlandia & 10.05 .1972 & członkostwo w WE & 70,88 & 83,10 \\
\hline 3 & Norwegia & 26.09 .1972 & członkostwo w WE & 79,20 & 46,50 \\
\hline 4 & Dania & 2.10 .1972 & członkostwo w WE & 90,14 & 63,29 \\
\hline 5 & Szwajcaria & 3.12 .1972 & członkostwa w EFTA & 52,00 & 72,50 \\
\hline 6 & Wielka Brytania & 5.06 .1975 & członkostwo w WE & 64,03 & 67,23 \\
\hline 7 & Grenlandia & 23.02 .1982 & członkostwo w WE & 74,91 & 45,96 \\
\hline 8 & Dania & 27.02 .1986 & JAE - Wspólny Rynek & 75,39 & 56,24 \\
\hline 9 & Irlandia & 26.05 .1987 & JAE - Wspólny Rynek & 44,09 & 69,92 \\
\hline 10 & Włochy & 18.06 .1989 & mandat dla PE & 85,40 & 88,06 \\
\hline 11 & Dania & 2.06 .1992 & Traktat z Maastricht & 82,90 & 49,30 \\
\hline 12 & Irlandia & 18.06 .1992 & Traktat z Maastricht & 57,30 & 69,10 \\
\hline
\end{tabular}

4 Określenia „europejskie” bądź też „unijne” są używane w stosunku do referendów w sprawach związanych z integracją europejską. Podobną logikę przyjęto w kontekście spraw o charakterze unijnym itd. Określenie „europejskie”, „unijne” w tekście nie są wzięte w cudzysłów.

${ }_{5} \mathrm{Na}$ uwagę zasługuje również fakt, iż w niektórych krajach przeprowadzano dwukrotnie głosowanie nad tą samą sprawą lub lekko zmodyfikowaną jej wersją. Po negatywnym wyniku pierwszego referendum, drugie kończyło się uzyskaniem odmiennego wyniku, czego przykładem jest Dania lub Irlandia. Zdarzało się również, iż na pytanie w dwu kolejnych referendach, społeczeństwo udzieliło negatywnej odpowiedzi. W tym przypadku przykład stanowić mogą referenda norweskie - dotyczące członkowstwa w UE. Dwa głosowania w tej kwestii zakończone zostały takim samym - negatywnym rezultatem.

6 Przypadek Grenlandii i Wysp Alandzkich. 


\begin{tabular}{|c|c|c|c|c|c|}
\hline 1 & 2 & 3 & 4 & 5 & 6 \\
\hline 13 & Francja & 20.09 .1992 & Traktat Maastricht & 69,69 & 51,05 \\
\hline 14 & Szwajcaria & 6.12 .1992 & członkostwo w EOG & 78,00 & 49,70 \\
\hline 15 & Lichtenstein & 12.12 .1992 & członkostwo w EOG & 87,00 & 55,81 \\
\hline 16 & Dania & 18.05 .1993 & Traktat z Maastricht (z wyłączeniami) & 85,50 & 56,77 \\
\hline 17 & Austria & 12.06 .1994 & członkostwo w UE & 82,35 & 66,58 \\
\hline 18 & Finlandia & 16.10 .1994 & członkostwo w UE & 70,40 & 56,88 \\
\hline 19 & Szwecja & 13.11.1994 & członkostwo w UE & 83,32 & 52,74 \\
\hline 20 & Wyspy Alandzkie & 20.11 .1994 & członkostwo w UE & 49,10 & 73,64 \\
\hline 21 & Norwegia & 28.11 .1994 & członkostwo w UE & 89,00 & 47,80 \\
\hline 22 & Lichtenstein & 9.04 .1995 & członkostwo w EOG & 82,05 & 55,88 \\
\hline 23 & Szwajcaria & 8.06 .1997 & kandydatura do UE & 35,00 & 25,90 \\
\hline 24 & Irlandia & 22.05 .1998 & Traktat z Amsterdamu & 56,26 & 61,74 \\
\hline 25 & Dania & 28.05 .1998 & Traktat z Amsterdamu & 76,24 & 55,10 \\
\hline 26 & Szwajcaria & 21.05 .2000 & umowy dwustronne z UE & 48,00 & 67,20 \\
\hline 27 & Dania & 28.09 .2000 & wprowadzenie euro (UGM) & 87,50 & 46,87 \\
\hline 28 & Szwajcaria & 4.03 .2001 & kandydatura do UE & 55,00 & 23,20 \\
\hline 29 & Irlandia & 7.06 .2001 & Traktat z Nicei & 34,79 & 46,13 \\
\hline 30 & Irlandia & 19.10 .2002 & Traktat z Nicei & 49,47 & 62,89 \\
\hline 31 & Malta & 8.03 .2003 & członkostwo w UE & 91,00 & 53,60 \\
\hline 32 & Słowenia & 23.03 .2003 & członkostwo w UE & 60,30 & 89,60 \\
\hline 33 & Węgry & 12.04 .2003 & członkostwo w UE & 45,60 & 83,70 \\
\hline 34 & Litwa & $10-11.05 .2003$ & członkostwo w UE & 63,30 & 89,90 \\
\hline 35 & Słowacja & $16-17.05 .2003$ & członkostwo w UE & 52,20 & 92,40 \\
\hline 36 & Polska & $7-8.06 .2003$ & członkostwo w UE & 58,80 & 77,50 \\
\hline 37 & Czechy & $13-14.06 .2003$ & członkostwo w UE & 55,20 & 77,30 \\
\hline 38 & Estonia & 14.09 .2003 & członkostwo w UE & 64,00 & 66,80 \\
\hline 39 & Szwecja & 14.09 .2003 & wprowadzenie euro & 82,60 & 41,80 \\
\hline 40 & Lotwa & 20.09 .2003 & członkostwo w UE & 72,50 & 67,00 \\
\hline 41 & Rumunia & 19.10 .2003 & Poprawka do konstytucji (UE akcesja) & 55,20 & 89,60 \\
\hline 42 & Hiszpania & 20.02 .2005 & Konstytucja dla Europy & 42,00 & 76,00 \\
\hline 43 & Francja & 29.05 .2005 & Konstytucja dla Europy & 69,37 & 45,33 \\
\hline 44 & Holandia & 1.06 .2005 & Konstytucja dla Europy & 62,80 & 38,40 \\
\hline 45 & Szwajcaria & 5.06 .2005 & traktat z Schengen & 56,63 & 54,63 \\
\hline 46 & Luksemburg & 10.07 .2005 & Konstytucja dla Europy & 90,44 & 56,52 \\
\hline 47 & Szwajcaria & 25.09 .2005 & przepływ osób - nowi członkowie UE & 54,51 & 55,98 \\
\hline 48 & Irlandia & 12.07 .2008 & Traktat z Lizbony & 53,10 & 46,60 \\
\hline 49 & Szwajcaria & 8.02 .2009 & przepływ osób - Bułgaria i Rumunia & 51,44 & 59,61 \\
\hline 50 & Szwajcaria & 17.05 .2009 & $\begin{array}{l}\text { Traktat z Schengen (paszporty biome- } \\
\text { tryczne i dokumenty podróży) }\end{array}$ & 38,77 & 50,15 \\
\hline 51 & Irlandia & 2.10 .2009 & Traktat z Lizbony & 59,00 & 67,10 \\
\hline 52 & Chorwacja & 22.01 .2012 & członkostwo w UE & 43,51 & 66,27 \\
\hline 53 & Irlandia & 31.05 .2012 & Pakt fiskalny & 50,53 & 60,37 \\
\hline
\end{tabular}

Źródlo: T. Christin, S. Hug, Referendums and citizen support for European Integration, „Comparative Political Studies" 2002, vol. 35 nr 5, s. 591; Initiative and Referendum Instiute - Europe, www.iri-europe.com ${ }_{2}$ 8.06.2006. 
Pierwsze głosowanie bezpośrednio związane z procesami integracyjnymi w Europie odbyło się w kwietniu 1972 r. i dotyczyło akcesji nowych państw do Wspólnoty Europejskiej ${ }^{7}$. Po francuskim referendum - w relatywnie krótkim czasie (maj-październik 1972) odbyły się trzy głosowania powszechne w sprawie akcesji Irlandii, następnie Norwegii, a potem Danii. Podczas gdy Irlandczycy i Duńczycy poparli członkowstwo swoich państw we Wspólnocie, to Norwegowie zdecydowali nie przyłączać się i pozostać poza nią. Kolejne referenda w sprawach „europejskich” - tym razem dotyczące pozostania w strukturach WE - przeprowadzono odpowiednio w 1975 r. w Wielkiej Brytanii i w 1982 r. na Grenlandii. Brytyjczycy poparli dalszą przynależność Zjednoczonego Królestwa do zjednoczonej Europy, natomiast Grenlandia jako pierwszy obszar, uzyskując autonomię, zrezygnowała z członkostwa. Warto w tym miejscu zaznaczyć, iż Grenlandia stanowi wyjątek na arenie europejskiej, gdyż jest jedynym terytorium, które po pewnym okresie członkostwa odłączyło się od Wspólnoty.

Kolejne dwa referenda - z roku 1986 i 1997 - dotyczyły ratyfikacji Jednolitego Aktu Europejskiego. Przedmiotem włoskiego referendum z 1989 r. była kwestia powierzenia mandatu Parlamentowi Europejskiemu. Wszystkie trzy głosowania zakończyły się wynikiem pozytywnym. Również nad traktatem - tym razem z Maastricht - głosowano w kolejnych referendach w Danii (dwukrotnie), Irlandii i Francji w latach 1992 i 1993. W pierwszym duńskim głosowaniu z czerwca 1992 r. wyborcy wypowiedzieli się negatywnie co do ratyfikacji Traktatu o UE. Po wypracowaniu tak zwanego Narodowego Kompromisu ${ }^{8}$, na 18 maja 1993 r. zarządzono ponowne referendum w sprawie ratyfikowania Traktatu. Tym razem Duńczycy zaakceptowali przedłożoną im do rozstrzygnięcia propozycję. Po pierwszym duńskim referendum, w referendach narodowych w Irlandii i we Francji opowiedziano się za ratyfikacją dokumentu.

Kolejnymi przykładami odwołania się do instytucji referendum w sprawach integracji europejskiej są głosowania powszechne, które miały miejsce w Szwajcarii i Lichtensteinie w 1992 r. Ich przedmiotem było przystąpienie obu państw do Europejskiego Obszaru Gospodarczego ${ }^{9}$. Obywatele Lichtensteinu opowiedzieli się za przystapieniem do tego stowarzyszenia państw, natomiast większość z głosujących Szwajcarów odpowiedziało w głosowaniu „Nie”. W związku z postawą tych drugich, wejście w życie porozumienia o EOG zostało odłożone w czasie.

Tak zwane nordyckie czy też skandynawskie rozszerzenie - negocjowane na początku lat 90-tych - zakończyło się kolejną falą referendów. W 1994 r. wyborcy z Austrii, Finlandii, Szwecji, Wysp Alandzkich i Norwegii wypowiadali się w sprawie

75 kwietnia 1972 r. Prezydent Pompidou na mocy art. 11 Konstytucji wydał dekret dotyczący przeprowadzenia referendum w sprawie rozszerzenia Wspólnot Europejskich (o Danię, Irlandię, Norwegię i Wielką Brytanię).

Zgodnie z założeniami porozumienia: Dania nie uczestniczy we wspólnej polityce obronnej i Unii Zachodnioeuropejskiej, nie partycypuje w strefie wspólnej waluty oraz wspólnej polityce ekonomicznej związanej z Europejską Unią Walutową, nie angażuje się w relacje dotyczące obywatelstwa Unii i nie akceptuje transferu suwerenności w obszarze sprawiedliwości i spraw policyjnych.

9 EOG został utworzony na podstawie porozumienia podpisanego 2 maja 1992 r. w Oporto. Członkami EOG są wszystkie państwa członkowskie Wspólnot Europejskich i państwa stowarzyszone w układzie EFTA, czyli Norwegia, Islandia i Lichtenstein. Szwajcaria również brała udział w negocjowaniu umowy, ale z powodu negatywnego wyniku referendum ostatecznie nie ratyfikowała układu. 
akcesji do UE. Obywatele czterech spośród wymienionych państw poparli swoje członkowstwo. Norwegowie po raz drugi odrzucili członkostwo swojego kraju w UE.

W 1995 r. w Lichtensteinie ponownie przeprowadzono referendum w sprawie porozumienia o EOG. Podobnie jak poprzednio - wyborcy opowiedzieli się za wejściem w życie porozumienia. W 1997 r. w Szwajcarii odbyło się referendum w sprawie kandydowania federacji do UE. Przy bardzo niskiej frekwencji wyborczej (na poziomie $35 \%$ ) Szwajcarzy sprzeciwili się włączaniu ich państwa w struktury unijne. Drugie referendum w tej samej sprawie przeprowadzono w marcu 2001 r. (inicjatywa ludowa „Ja zu Europa” ${ }^{10}$, jednak również i ono zakończyło się odmową elektoratu. Rok wcześniej Szwajcarzy wtedy po raz czwarty mieli okazję głosować w sprawie bezpośrednio związanej z integracją europejską. Tym razem referendum dotyczyło zawarcia przez Szwajcarię umów bilateralnych z UE. Głosowanie zakończyło się podjęciem pozytywnej decyzji, a propozycja przedłożona do rozstrzygnięcia elektoratowi zyskała prawie $70 \%$ poparcia uczestniczących. Dodać należy, iż w Szwajcarii przeprowadzono jeszcze cztery głosowania powszechne regulujące m.in. kwestie wynikłe z przepisów traktatu z Schengen (referenda z czerwca 2005 i maja 2009 r.), którego Konfederacja jest od roku 2005 również sygnatariuszem oraz kwestie związane ze swobodnym przepływem osób z nowych państw członkowskich UE (referenda z września 2005 i lutego 2009 r.). Wszystkie głosowania zakończyły się pozytywnymi odpowiedziami Szwajcarów.

Po podpisaniu Traktatu Amsterdamskiego, w maju 1998 r. w Irlandii oraz Danii przeprowadzono referenda ratyfikacyjne - w obu przypadkach postanowiono zaakceptować dokument. Nieco po ponad 2 latach od referendum nad Traktatem Amsterdamskim, we wrześniu 2000 r. w Danii przeprowadzono - zakończone negatywną odpowiedzią wyborców - głosowanie w sprawie przyjęcia waluty euro.

Nad Traktem z Nicei głosowano wyłącznie w Irlandii - za to dwukrotnie: w roku 2001 i 2002. W pierwszym referendum Irlandczycy wyrazili swoją niechęć wobec Traktatu, natomiast głosowanie przeprowadzone rok później, zakończyło się wynikiem pozytywnym. Konsekwencją referendum irlandzkiego z 2002 r. była kolejna - największa fala referendów, tym razem akcesyjnych.

W roku 2003 - w okresie od marca do października - przeprowadzono jedenaście głosowań związanych z integracją europejską. Dziewięć referendów akcesyjnych odbyło się w państwach należących do Europy Środkowej i Wschodniej, które od 1 maja 2004 r. stać się miały pełnoprawnymi członkami UE. Wszystkie głosowania zakończyły się poparciem akcesji. We wrześniu 2003 r. w Szwecji odbyło się zakończone negatywną odpowiedzią referendum w sprawie przyjęcia waluty euro. Ostatnie referendum, jakie odbyło się w 2003 r., przeprowadzono w Rumunii, a jego przedmiotem były zainicjowane przez prezydenta Illiescu poprawki konstytucyjne związane m.in. z przyjęciem Rumunii do UE (a także NATO) ${ }^{11}$. Wynik głosowania - przy ponad 55-procentowej frekwencji - okazał się pozytywny.

${ }^{10}$ B. Wiśniewska-Paź, Tytułem wstępu. Szwajcaria wobec Unii Europejskiej-stan obecny i perspektywy, w: Fenomen Szwajcarii wobec Unii Europejskiej. Przyczyny i skutki szczególnej pozycji Konfederacji Helweckiej w Europie, red. B. Wiśniewska-Paź, Warszawa 2009, s. 15.

${ }_{11}$ Constitutional reform, Center for Research on Direct Democracy, http://www.c2d.ch/detailed_display.php?lname $=$ votes\&table $=$ votes\&page $=1 \&$ parent $i d=\&$ sublinkname $=$ results\&id=39138\&profile $=1 \&$ continent $=$ Europe $\&$ insti $=\&$ res $=1 \&$ year $=2000-2009 \&$ page $=1,22.09 .2012$. 
Kolejne referenda w sprawach UE dotyczyły ratyfikacji Traktatu ustanawiajacego Konstytucje dla Europy. W lutym 2005 r. po raz pierwszy w sprawach integracji zagłosowali Hiszpanie, którzy przy frekwencji $42 \%$ uczestniczących wyrazili zgodę na ratyfikację tzw. Konstytucji dla Europy. 29 maja i 1 czerwca tego samego roku przeprowadzono referenda odpowiednio we Francji i w Holandii ${ }^{12}$ - w obu przypadkach decyzja wyborców była negatywna, co też wpłynęło na zablokowanie procesu ratyfikacji traktatu konstytucyjnego w państwach członkowskich UE. Co prawda, 10 lipca przeprowadzono jeszcze referendum w Luksemburgu, jednak to głosowanie miało w dużej mierze wymiar plebiscytarny, bowiem wiązało się z potwierdzeniem poparcia społecznego dla premiera Junckera ${ }^{13}$.

$\mathrm{Na}$ liście referendów europejskich odnotować należy jeszcze dwa referenda irlandzkie nad Traktatem z Lizbony. Można rzec, iż w tym przypadku powtórzył się scenariusz z lat 2001-2002: w pierwszym głosowaniu Irlandczycy sprzeciwili się ratyfikowaniu Traktatu, natomiast w drugim referendum przeprowadzonym po 15 miesiącach od pierwszego zadeklarowali poparcie dla dalszego pogłębiania integracji w Europie.

Do chwili obecnej ${ }^{14}$ odbyły się jeszcze dwa referenda w sprawach „unijnych”. Oba przeprowadzono w 2012 r.: 22 stycznia Chorwaci głosowali nad przystapieniem ich kraju do UE, natomiast ostatnim jak do tej pory głosowaniem w sprawach europejskich było irlandzkie referendum w sprawie przyjęcia zw. paktu fiskalnego. Oba głosowania zakończyły się pozytywnym wynikiem.

Szczegółowa analiza danych w tabeli pozwala sformułować kilka - wydaje się - ważnych wniosków.

Liczba referendów państwowych przeprowadzonych w sprawach związanych w różnym stopniu z integracją europejską stanowi niewątpliwy dowód na istotną rolę, jaka przypisywana jest głosowaniom powszechnym właśnie w rozstrzyganiu kwestii europejskich. Liczba głosowań dowodzi także tego, że referendum stało się popularnym narzędziem demokracji bezpośredniej, za pośrednictwem którego poszczególne narody wyrażają swoją opinię co do przedkładanych im spraw - często natury ponadnarodowej.

Państwa członkowskie UE, a także kilka państw tzw. trzecich (nie będących w strukturach UE, ale pozostających z Unią w różnego rodzaju relacjach np. na mocy Układu z Schengen) wykorzystywały referenda wielokrotnie przy kształtowaniu struktur Unii, ustalaniu warunków i kierunków polityki integracyjnej na kontynencie europejskim. W zależności od przedmiotu głosowania wszystkie referenda tzw. europejskie można podzielić na kilka kategorii.

Na pierwszą składają się referenda w sprawie akcesji lub dalszego członkostwa we Wspólnocie. Do tej grupy zakwalifikowano głosowania powszechne, w których oby-

12 Godzi się przy tym zauważyć, iż referendum holenderskie było pierwszym tego rodzaju głosowaniem w historii Holandii od $1900 \mathrm{r}$. Elektorat tego państwa - pomimo toczącej się debaty nad wprowadzeniem instytucji demokracji bezpośredniej do porządku prawnego - nigdy przedtem nie miał okazji głosować w referendum ogólnokrajowym; M. Musiał-Karg, Referendum w państwach europejskich. Teoria, praktyka, perspektywy, Toruń 2008, s. 299.

13 Który deklarował, ze jeżeli wyborcy nie poprą (w praktyce „Zablokowanej” już Konstytucji dla Europy), to ten poda się do dymisji.

${ }^{14}$ Stan na dzień 1 listopada 2012 r. 
watele któregoś z państw europejskich pytani byli, czy ich kraj powinien dołączyć do wspólnoty europejskiej (ratyfikować traktat akcesyjny) lub pozostać dalej członkiem tej europejskiej struktury ${ }^{15}$. Przeprowadzono łącznie 24 takie głosowania: 5 - w sprawie akcesji lub członkostwa we WE, 1 - w sprawie włączenia się do EFTA, 3 - w kwestii członkostwa w EOG oraz 15 - w kwestii akcesji do UE.

Druga grupa zawiera referenda, których przedmiotem było wyrażenie zgody na ratyfikację któregoś z traktatów europejskich. Do tej grypy zaliczono 16 głosowań: 2 głosowania nad $J A E^{16}, 4$ - w sprawie Traktatu z Maastricht, 2 - w sprawie Traktatu Amsterdamskiego, po 2 irlandzkie referenda dotyczące Traktatu z Nicei oraz Traktatu z Lizbony, a także 4 referenda w sprawie ratyfikowania Traktatu ustanawiajacego Konstytucję dla Europy.

$\mathrm{Na}$ trzecią grupę składa się 13 referendów państwowych, które związane były z innymi ważnymi materiami o charakterze europejskim: referendum francuskie w sprawie rozszerzenia WE, włoskie referendum w sprawie legitymizacji mandatu dla PE, 2 szwajcarskie referenda dotyczące kandydowania do UE, 5 dotyczących różnych umów dwustronnych z UE, duńskie i szwedzkie dotyczące euro, a także rumuńskie referendum przeprowadzone w celu zmian konstytucji wynikających z przyszłej akcesji oraz irlandzkie referendum z 2012 r., którego przedmiotem był tzw. pakt fiskalny.

Powyższy podział referendów w zależności od przedmiotu głosowania pozwala sformułować wniosek, iż w europejskich referendach dominują dwa rodzaje problemów przedkładanych do rozstrzygnięcia wyborcom: po pierwsze - referenda akcesyjne, a po drugie referenda w sprawie traktatów. Obywatele państw europejskich coraz częściej mają okazję wyrażać swoje zdanie w tych sprawach - mimo iż (szczególnie kwestie traktatów) są bardzo skomplikowane i złożone.

Warto ponadto zauważyć, iż właściwie od roku 1989, kiedy na kontynencie europejskim rozpoczęły się procesy transformacyjne w państwach Europy Środkowej i Wschodniej, przeprowadzono więcej niż 80\% liczby wszystkich referendów w kwestiach integracji, a dodatkowo - tylko na przestrzeni ostatnich 13 lat (od roku 2000) głosowań europejskich było aż 28. Liczby te stanowią o bardzo dużej dynamice procesów integracyjnych w Europie oraz o chęci poszczególnych państw do przekazywania wspólnych unijnych spraw w ręce obywateli.

Bardzo ważnym, z punktu widzenia wykorzystania instytucji referendum w procesie integracji europejskiej jest fakt, iż kilka państw członkowskich UE ani razu nie korzystało z takiego sposobu decydowania. Należy tu wymienić Belgię, Grecję, Cypr, Niemcy, Portugalię i Bułgarię. O ile Belgia czy Niemcy są państwami założycielskimi Wspólnoty i nie stosują praktycznie instytucji referendum w procesach podejmowania

15 Do tej grupy referendów nie zaliczono francuskiego głosowania z 23 kwietnia 1972 r., w którym Francuzi wyrazili swoją akceptację dla powiększania WE. Przedmiotem tego referendum nie była bowiem kwestia członkostwa Francji, ale poszerzenie WE o inne państwa.

${ }_{16} \mathrm{Z}$ racji, iż referenda w sprawie $J A E$ są bezpośrednio związane z tzw. wspólnym rynkiem, można by je zaliczyć do trzeciej grupy - zawierającej referenda w różnych europejskich kwestiach. $Z$ faktu, iż głosowania dotyczyły traktatu składającego się na prawo pierwotne UE, postanowiono zakwalifikować je do drugiej grupy głosowań. 
decyzji państwowych, to w przypadku Cypru, Grecji, Portugalii czy Bułgarii sytuację tę uznać należy za wyjątkową na scenie europejskiej.

Jeśli chodzi o państwo, w którym najwięcej razy rozstrzygano sprawy integracji w drodze referendum, to zaznaczyć należy, iż zdecydowanymi liderami w tej kwestii są Szwajcaria i Irlandia, gdzie przeprowadzono po 9 referendów o tej tematyce. Wśród państw członkowskich UE Irlandia jest państwem, gdzie właściwie wszystkie sprawy unijne rozstrzyga się $w$ drodze referendum. $Z$ kolei w drugim przypadku - z racji, iż instytucje demokracji bezpośredniej są najbardziej spośród państw świata rozwinięte w Konfederacji Szwajcarskiej, a kraj ten określany jest mianem „,perły demokracji bezpośredniej", czołowe miejsce tego państwa w tym rankingu nie powinno budzić zdziwienia. Warto zauważyć, iż 1/3 wszystkich referendów w sprawie integracji odbyła się w obu tych państwach.

Analizując przedmiot referendów, warto dodać, iż proces integracji europejskiej przyczynił się do wykształcenia niezwykle istotnego typu głosowania - a mianowicie referendum akcesyjnego. Przeważająca liczba dzisiejszych państw członkowskich UE kwestię członkostwa przekazała do rozstrzygnięcia elektoratowi jeszcze przed oficjalnym włączeniem się w struktury Unii. Większości rozszerzeń UE towarzyszyły głosowania akcesyjne w poszczególnych państwach kandydujących. Zaznaczyć jednak należy, iż nie we wszystkich państwach kandydujących do UE, przeprowadzenie referendum akcesyjnego stanowi warunek sine qua non wejścia w UE. Referendów akcesyjnych nie przeprowadzano w Wielkiej Brytanii (nad kwestią członkostwa głosowano jednak w 1975 r.), w Grecji, Hiszpanii i Portugalii, na Cyprze, w Rumunii (przeprowadzono referendum dostosowujące konstytucję do przyszłego członkostwa) i Bułgarii. W tych państwach stosowne decyzje podjęte zostały przez parlamenty narodowe. Dodatkowo, zauważyć należy, iż nie we wszystkich państwach wynik głosowania akcesyjnego był formalnie wiążący. Ze względu jednak na wyjątkowe znaczenie kwestii członkostwa w Unii, w większości państw, gdzie zdecydowano się odwołać do woli suwerena i przeprowadzić referenda w sprawie akcesji, utarł się zwyczaj polegający na tym, iż rządy państw, w których wynik referendum nie jest formalnie wiążący, stosują się do opinii wyrażonej przez wyborców w głosowaniu ${ }^{17}$.

Ponadto, uwzględniając przedmiot referendów w państwach członkowskich UE, można wprowadzić dychotomiczny podział na głosowania dot. akcesji do UE i członkostwa w UE (te głosowania zwykle dotyczą wymiaru poszerzania UE) oraz na referenda pogłębiające ${ }^{18}$, czyli takie, które inicjowane są w celu opowiedzenia się społeczeństw poszczególnych państw członkowskich co do reform o charakterze pogłębiającym proces integracji ${ }^{19}$. Za referenda pogłębiające uznać zatem można wszystkie 21 referen-

17 Referenda akcesyjne na Malcie, w Stowenii i na Węrzech, „Biuletyn Analiz UKIE” 2003, nr 11, http://www.biuletyn.ukie.gov.pl, 17.03.2006.

${ }^{18}$ Zaznaczyć należy, iż głosowanie takie nie jest w żadnym wymiarze terminem natury prawnej, jednak wydaje się być niezwykle ważne jako pojęcie politologiczne służące analizie politologicznej referendów w UE.

19 T. R. Szymczyński, Dylematy wokót instytucji referendum europejskiego, „Rocznik Integracji Europejskiej” 2007, nr 1, s. 240; por.: T. R. Szymczyński, On Some Consequences of the Contemporary Shape of the European Referendum, w: The Road Europe Travelled Along. The Evolution of the 
dów, których przedmiotem były: ratyfikacje poszczególnych traktatów unijnych, kwestia rozszerzenia WE, przyjęcie waluty euro, mandat dla PE i pakt fiskalny.

Analizując proces organizowania referendów w różnych sprawach europejskich zauważyć należy, iż głosowania w tej samej kwestii (np. akcesja do UE czy zgoda na ratyfikację jakiegoś traktatu) organizowane są zazwyczaj w określonym porządku. Ustalenie określonej kolejności referendów powoduje powstanie tzw. efektu domina (efektu kuli śnieżnej czy kaskadowej organizacji referendów). Polega on na tym, że wyniki referendów w państwach głosujących jako pierwsze, wpływają na wynik kolejnych głosowań odbywających się w późniejszym (choć czasowo nieodległym) terminie. Istnienie efektu domina zaobserwować można było praktycznie przy każdym rozszerzeniu $\mathrm{UE}^{20}$, a także przy okazji ratyfikacji traktatów unijnych (np. Traktatu z Maastricht czy Traktatu ustanawiającego Konstytucję dla Europy).

Analiza doświadczeń państw europejskich pozwala sformułować kilka wniosków dotyczących praktyki referendalnej w sprawach integracji.

Po pierwsze, Europejczycy są pionierami jeżeli chodzi o liczbę państw przeprowadzających referenda oraz liczbę głosowań nad jedną szeroko pojmowaną kwestią.

Analiza frekwencji wyborczej i rezultatów referendów może zdecydowanie pomóc w określeniu roli, jaka przypisywana jest tym głosowaniom w państwach Europy.

Dane $\mathrm{z}$ tabeli 2 dowodzą, iż średnia frekwencja w głosowaniach jest relatywnie wysoka - na poziomie $64,68 \%$, co świadczy o dużym zaangażowaniu wyborców w europejskie procesy decyzyjne. W państwach członkowskich średnia partycypacja wynosi około $65,5 \%$, a w państwach spoza UE - jest niższa o około 1\%. Jeśli chodzi o frekwencję w głosowaniach dotyczących jednego przedmiotu, to zauważyć należy, iż wszystkie kategorie głosowań wyróżnione w tabeli 2 (poza pozostałymi kwestiami w państwach nie będących członkami UE) cieszą się wysokim poziomem uczestnictwa obywateli - od 63 do $70 \%$.

W kontekście rezultatów referendów europejskich istotnym zapewne jest fakt, iż na 53 referenda przeprowadzone w UE, 40 zakończyło się zaakceptowaniem przedmiotu głosowania (32 w państwach UE), a 13 (8 w państwach UE) zakończyło się odpowiedzią negatywną.

EEC/EU Institutions and Policies, red. D. Preda, D. Pasquinucci, Series: Euroclio - Vol. 54, Bruxelles 2010, s. 133-150; T. R. Szymczyński, Ireland, the Lisbon Treaty and the European Referendum, „European Governance", URGE, Vol. 2, No. 2, July 2008.

20 Szczególnego znaczenia efekt domina nabrał przed największym rozszerzeniem z roku 2004, bowiem sprawa związana z kolejnością przeprowadzania referendów akcesyjnych przy okazji tzw. środkowo-wschodniego rozszerzenia była przedmiotem politycznych uzgodnień przywódców państw Grupy Wyszehradzkiej. Zauważyć warto, że „zakładany w państwach przystępujących efekt sekwencyjnej kolejności referendów został zrealizowany", a znamiennym wydaje się być fakt, iż pierwsze w kolejności referenda w znacznej mierze wpływały na określone postawy społeczeństw i na wyniki referendów w państwach głosujących w późniejszym terminie. Wysoki odsetek wyborców popierających akcesję we wszystkich państwach kandydujących (z wyjątkiem Malty) był rezultatem m.in. „przykładu” płynącego z referendów organizowanych wcześniej. Wynikał także - jak zostało zaznaczone wcześniej - $\mathrm{z}$ chęci dołączenia przez państwa środkowo- $\mathrm{i}$ wschodnioeuropejskie do państw Europy Zachodniej. R. Dziewulski, B. Otachel, Referenda akcesyjne na Litwie, Stowacji, Czechach, Estonii $i$ Łotwie, „Biuletyn Analiz UKIE” 2003, nr 13, s. 61. 
Referenda w sprawach związanych z integracją europejską (1972-2012)

\begin{tabular}{|c|c|c|c|c|c|c|}
\hline & \multirow[b]{2}{*}{ Rodzaj kwestii } & \multirow{2}{*}{$\begin{array}{c}\text { Liczba } \\
\text { głoso- } \\
\text { wań }\end{array}$} & \multirow{2}{*}{$\begin{array}{c}\text { średnia } \\
\text { frekwen- } \\
\text { cja }(\%)\end{array}$} & \multirow{2}{*}{$\begin{array}{l}\text { Średnia od- } \\
\text { powiedzi na } \\
\text { „Tak" (\%) }\end{array}$} & \multicolumn{2}{|c|}{ Rezultat } \\
\hline & & & & & przyjęte & odrzucone \\
\hline \multirow{10}{*}{$\begin{array}{l}\text { Państwa } \\
\text { członkowskie } \\
\text { UE }\left(28^{*}\right)\end{array}$} & AKCESJA I CZLONKOSTWO & 18 & 66,19 & 65,77 & 17 & 1 \\
\hline & TRAKTATY & 16 & 63,02 & 56,76 & 11 & 5 \\
\hline & $-\mathrm{JAE}$ & 2 & 59,74 & 63,08 & 2 & 0 \\
\hline & - Traktat z Maastricht & 4 & 73,85 & 53,55 & 3 & 1 \\
\hline & - Traktat z Amsterdamu & 2 & 66,25 & 58,42 & 2 & 0 \\
\hline & - Traktat z Nicei & 2 & 42,13 & 54,51 & 1 & 1 \\
\hline & - Konstytucja dla Europy & 4 & 66,15 & 54,06 & 2 & 2 \\
\hline & - Traktat z Lizbony & 2 & 56,05 & 56,85 & 1 & 1 \\
\hline & POZOSTAŁE KWESTIE & 6 & 70,25 & 65,83 & 4 & 2 \\
\hline & Lącznie & 40 & 65,53 & 62,18 & 32 & 8 \\
\hline \multirow[t]{3}{*}{$\begin{array}{l}\text { Pozostałe } \\
\text { państwa (3) }\end{array}$} & $\begin{array}{l}\text { AKCESJA I KANDYDATURA } \\
\text { (EOG/WE/EFTA/UE) }\end{array}$ & 8 & 69,65 & 47,16 & 3 & 5 \\
\hline & POZOSTAŁE KWESTIE & 5 & 49,87 & 57,51 & 5 & 0 \\
\hline & Lącznie & 13 & 62,05 & 51,14 & 8 & 5 \\
\hline \multicolumn{2}{|c|}{ Wszystkie referenda } & 53 & 64,68 & 59,47 & 40 & 13 \\
\hline
\end{tabular}

* Uwzględniając Chorwację.

Źródlo: Opracowanie własne.

Nie budzi żadnych wątpliwości fakt, iż jednym z najważniejszych efektów referendów związanych ze sprawami integracji europejskiej jest możliwość wyrażania woli przez poszczególne narody, nie tylko w sprawach o znaczeniu państwowych, ale jednocześnie w kwestii o charakterze ponadnarodowym - europejskim. W referendach unijnych przedmiot głosowania nie jest związany wyłącznie z państwem głosującym, ale i z pozostałymi państwami będącymi członkami Unii. Integracja europejska pociaga pewne następstwa $\mathrm{w}$ dziedzinie relacji między ponadnarodowością a suwerennością państwową i narodową. Widoczne jest to m.in. w procedurach referendalnych. Skutki referendów bowiem - pomimo, że głosowania są przeprowadzane w poszczególnych państwach - mają wpływ na całą UE i odczuwane są przez wszystkie państwa członkowskie. Elektoraty na szczeblu państwowym podejmują więc decyzje o charakterze ponadnarodowym. Ta właściwość wydaje się być głównym walorem referendów w sprawach związanych z integracją europejską ${ }^{21}$.

\section{Pomysły „paneuropejskiego" referendum}

Dla niniejszych rozważań ważnym jest fakt, że w dyskusji nad sposobem ratyfikacji Traktatu ustanawiajqcego Konstytucję dla Europy szerokie grono zwolenników uzyskała opcja ustanowienia instytucji ogólnoeuropejskiego referendum. Taka transnarodowa

21 Przykładem w tym zakresie mogą być: francuskie referendum z 1972 (które praktycznie „otworzyło" proces integracji na pozostałe państwa europejskie), irlandzkie referendum w sprawie Traktatu z Nicei (blokujące poszerzanie UE o państwa z byłego bloku wschodniego), czy francuskie referendum (odrzucające „Konstytucję dla Europy” i wprowadzające UE - w kryzys). 
instytucja demokracji bezpośredniej mogłaby być wykorzystywana w celu rozstrzygania o najważniejszych zagadnieniach integracji w Europie. Jeszcze w 2003 r. przedstawiono propozycję ratyfikacji przygotowywanej Konstytucji dla Europy w referendum zorganizowanym na poziomie europejskim. Głosowanie takie miałoby być odpowiednikiem wyborów do Parlamentu Europejskiego. Uczeni zajmujący się tematyką integracji europejskiej proponowali różne modele takiego europejskiego głosowania. Michael Netwich i Joseph Weiler argumentowali na rzecz prostej podwójnej większości $^{22}$. Astrid Epiney sugerowała podwójną kwalifikowaną większośćc ${ }^{23}$, zaś Heidrun Abromeit większość we wszystkich uczestniczących krajach ${ }^{24}$.

Oczywiście, europejskie transnarodowe referendum mogłoby być narzędziem niezwykle przydatnym dla UE, jednak taki sposób ratyfikacji np. konstytucji europejskiej czy innego traktatu unijnego podpisanego przez przedstawicieli rządów państw członkowskich byłby olbrzymim wyzwaniem dla wszystkich krajów unijnych i mógłby spowodować znaczne opóźnienia wejścia w życie takiego dokumentu. W opinii zwolenników takie referendum europejskie mogłoby być przeprowadzone w jednym dniu i być swego rodzaju świętem europejskiego demos ${ }^{25}$. Wśród zalet głosowania, w którym kraje członkowskie UE stworzyłyby jeden okręg wyborczy, wymieniano przede wszystkim to, że takie referendum mogłoby być ważnym krokiem w kierunku dalszego zwiększania świadomości bycia obywatelami Europy oraz silniejszej identyfikacji z UE. Ponadto takie głosowanie europejskie przyczyniłoby się do większego zaangażowania obywateli w sferę publiczną oraz do tego, by na szczeblu europejskim większa uwaga poświęcana była polityce. Przy założeniu, że głosowanie ,przyciagnęłoby” do lokali wyborczych tłumy uprawnionych, dodatkowy jego atut stanowiłby fakt zademonstrowania, że Unia jest potrzebna. Negatywnymi konsekwencjami takiego referendum mogłoby być zwiększenie istniejących napięć i rozbieżności pomiędzy poszczególnymi państwami członkowskimi $\mathrm{UE}^{26}$.

Przy rozpatrywaniu możliwości przeprowadzenia paneuropejskiego głosowania powszechnego należałoby również uwzględnić fakt, że nie wszystkie państwa należące do UE mają doświadczenia związane z wykorzystaniem form demokracji bezpośredniej w swojej praktyce politycznej. Ponadto, zauważyć można istotne różnice pomiędzy procedurami rządzącymi instytucją referendum w poszczególnych państwach członkowskich ${ }^{27}$.

22 M. Nentwich, Opportunity structures for citizens' participation. The case of the European Union, w: Political Theory and the European Union. Legitimacy, constitutional choice and citizenship, red. A. Weale, M. Nentwich, London 1998, s. 136; J. Weiler, The European Union belongs to its Citizens: Three Immodest Proposals, „European Law Review” 1997, nr 22, s. 153.

23 A. Epiney, Le référendum européen, w: Le référendum européen, red. A. Auer, J.-F. Flauss, Bruksela 1997, s. 310.

24 H. Abromeit, Wozu braucht man Demokratie? Die postnationale Herausforderung der Demokratietheorie, Opladen 2000, s. 182.

25 B. Nowak, Europejski Konwent. System czy porażka, Centrum Stosunków Międzynarodowych, „Raporty i Analizy” 2003, nr 4, s. 10.

26 M. Mokre, J. Pollak, S. Puntscher Riekmann, P. Slominski, Narody Europy a Europejski Traktat Konstytucji, Austiacka Akademia Nauk, Convue-30, s. 7-8.

27 Podczas gdy w Wielkiej Brytanii możliwe jest przyjęcie ad hoc ustawy o referendum, to według art. 138 Konstytucji Republiki Włoskiej taka ustawa musi być stworzona ex novo dla każdej kolejnej propozycji. 
Co więcej, w niektórych państwach Unii nie istnieją żadne akty prawne regulujące przeprowadzenie referendum. Kolejną wadą referendum europejskiego mogłaby być niezbyt wysoka frekwencja. Dodać warto, że od rozszerzenia 2004 r., UE ma do czynienia z problemem niskiej partycypacji przy okazji wyborów do Parlamentu Europejskiego (2004 i 2009). Do frekwencji na niższym niż poprzednio poziomie przyczyniła się głównie niska frekwencja w nowych państwach członkowskich z Europy Środkowej i Wschodniej. Tam średnia partycypacja wyniosła około 31\% w roku 2004 i nieco więcej w roku 2009. Godzi się przy tym zauważyć, że w Unii problem ten może narastać wraz ze zwiększaniem się liczby członków Wspólnoty. Analogicznie, niska frekwencja mogłaby wystapić również w głosowaniu referendalnym na poziomie UE. Niewątpliwie, przyczyniłoby się to do jeszcze większego pogłębienia problemu deficytu demokracji w UE, a w przypadku negatywnego rezultatu referendum, realna stałaby się dezintegracja Europy ${ }^{28}$. Należy zatem uświadomić sobie, że podobnie jak w przypadku porównania państwowych wyborów parlamentarnych z wyborami do PE, referenda europejskie mogłyby być traktowane przez elektorat jako referenda drugorzędne w stosunku do referendów narodowych. Takie second-order referenda byłyby wówczas wykorzystywane jako dodatkowa możliwość wyrażenia opinii ${ }^{29}$. Jednak prawdopodobnie nie byłyby one postrzegane jako instytucja o takim znaczeniu jak referenda państwowe.

Podsumowując kwestię paneuropejskiego referendum, zaznaczyć należy, iż mimo że instytucja taka mogłaby stanowić interesujący wyjątek w skali całego globu, to praktycznie nie ma szans na jej wdrożenie w życie. Spowodowane to jest m.in. brakiem doświadczeń (lub złymi doświadczeniami) niektórych państw UE (np. Niemiec) w wykorzystaniu instytucji demokracji bezpośredniej, różnicami w ustawodawstwie poszczególnych państw członkowskich w zakresie wykorzystania instytucji referendum, a także obawą o to, że referendum ponadnarodowe traktowane będzie przez społeczeństwo jako głosowanie o drugorzędnym charakterze.

\section{Europejska inicjatywa obywatelska}

Obok praktycznie niemożliwych do zrealizowania pomysłów na ogólnoeuropejskie referendum, państwa członkowskie UE postanowiły w ustawodawstwie unijnym dać miejsce innej instytucji demokracji bezpośredniej o charakterze szerszym niż narodowy - a mianowicie europejskiej inicjatywie obywatelskiej.

Warto nadmienić, iż jednym z głównych powodów zainicjowania debaty o wdrożeniu narzędzi demokracji bezpośredniej było przekonanie o istnieniu w UE tzw. deficytu demokratycznego, a w związku z tym o konieczności minimalizowania tego negatywnego zjawiska i przybliżenia obywateli do władzy w UE, a także zwiększenia ich zaangażowania w procesy decyzyjne w zjednoczonej Europie.

28 M. Mokre, J. Pollak, S. Puntscher Riekmann, P. Slominski, Narody Europy..., op. cit., s. 8.

29 S. Bizner Hobolt, Europe and the Ballot: Voting Behaviour in Referendums on European Integration Marburg 2003, s. 3-4, http://www.intstudies.cam.ac.uk/people/students/info/hobolt_paper.pdf, 9.02.2004. 
Mimo iż pomysły ustanowienia instytucji europejskiej inicjatywy obywatelskiej pojawiły się już w latach 80-tych, a w $1996 \mathrm{r}$. jedna z takich propozycji została odrzucona (austriacko-włoska propozycja zwana od nazwisk ministrów spraw za granicznych tych państw inicjatywą Schüssel/Dini), to najbardziej podatnym gruntem na propozycję wdrożenia inicjatywy europejskiej okazały się prace nad przygotowaniem Traktatu ustanawiajacego Konstytucję dla Europy. Pomysł ten był intensywnie forsowany przez przedstawicieli różnorodnych organizacji pozarządowych oraz think-thanków promujących demokrację bezpośrednią (np. IRI-Europe), co poskutkowało umieszczeniem zapisów o europejskiej inicjatywie europejskiej w tekście Konstytucji dla Europy praktycznie w ostatniej chwili prac Konwentu Europejskiego - przed podpisaniem roboczej wersji Traktatu (w dniu 12 czerwca 2003 r.). Mimo wstrzymania procesu ratyfikowania Konstytucji dla Europy (po negatywnych referendach we Francji i w Holandii) i konieczności przygotowania $\mathrm{w}$ jej miejsce nowego traktatu, przepisy dotyczące europejskiej inicjatywy obywatelskiej postanowiono zachować i włączono je do treści Traktatu z Lizbony. Art. 11 ust. 4 ratyfikowanego Traktatu brzmi: „Obywatele Unii w liczbie nie mniejszej niż milion, mający obywatelstwo znacznej liczby Państw Członkowskich, mogą podjąć inicjatywę zwrócenia się do Komisji Europejskiej o przedłożenie, w ramach jej uprawnień, odpowiedniego wniosku w sprawach, w odniesieniu do których, zdaniem obywateli, stosowanie Traktatów wymaga aktu prawnego Unii”.

Aby nadać bieg inicjatywie obywatelskiej, musi ona zostać poparta przez co najmniej milion obywateli UE pochodzących z przynajmniej 7 spośród 27 państw członkowskich. W przypadku każdego z tych 7 państw wymagane jest osiagnięcie minimalnej liczby deklaracji poparcia. Przepisy proceduralne dotyczące europejskiej inicjatywy obywatelskiej określono w rozporządzeniu UE przyjętym przez Parlament Europejski i Radę w lutym 2011 r. ${ }^{30}$ Dodać należy, że wszystkie przygotowywane do złożenia inicjatywy rejestruje się w jednym portalu, którym zarządza Komisja Europejska: http://ec.europa.eu/citizens-initiative.

Zbieranie podpisów pod wnioskiem inicjatywy, nie wymaga zapewnienia, by na liście znalazły się podpisy obywateli każdego państwa członkowskiego ${ }^{31}$. Deklaracje poparcia należy jednak zgromadzić ${ }^{32}$ tak, by zebrać minimalną liczbę deklaracji z co najmniej - jak już wspomniano - siedmiu państw członkowskich (wymaganą liczbę podpisów z poszczególnych państw przedstawiono na wykresie 1).

W ciągu trzech miesięcy od przedłożenia inicjatywy, pod którą zebrano wymaganą liczbę podpisów, Komisja Europejska za pośrednictwem swoich przedstawicieli ma za zadanie spotkać się z organizatorami inicjatywy, by ci mogli wyjaśnić szczegółowo kwestie, jakich dotyczy inicjatywa. Oprócz tego, inicjatorzy mają możliwość zaprezen-

\footnotetext{
30 Rozporządzenie Parlamentu Europejskiego i rady (UE) nr 211/2011 z dnia 16 lutego 2011 r. w sprawie inicjatywy obywatelskiej, „Dziennik Urzędowy Unii Europejskiej” L 65/1, http://eur-lex.europa.eu/LexUriServ/LexUriServ.do?uri=OJ:L:2011:065:0001:0022:PL:PDF, 15.10.2012.

31 Europejska inicjatywa obywatelska, Komisja Europejska, http://ec.europa.eu/citizens-initiative/public/basic-facts, 15.10.2012.

${ }^{32}$ Rozporządzenie wykonawcze Komisji (UE) nr 1179/2011 z dnia 17 listopada 2011 r. ustanawiajace specyfikacje techniczne w odniesieniu do systemów zbierania deklaracji on-line na mocy rozporzadzenia Parlamentu Europejskiego i Rady (UE) nr 211/2011 w sprawie inicjatywy obywatelskiej, http://eur-lex.europa.eu/LexUriServ/LexUriServ.do?uri=OJ:L:2011:301:0003:0009:PL:PDF, 15.10.2012.
} 
Wykres 1. Minimalna liczba sygnatariuszy, przypadającą na państwo czlonkowskie

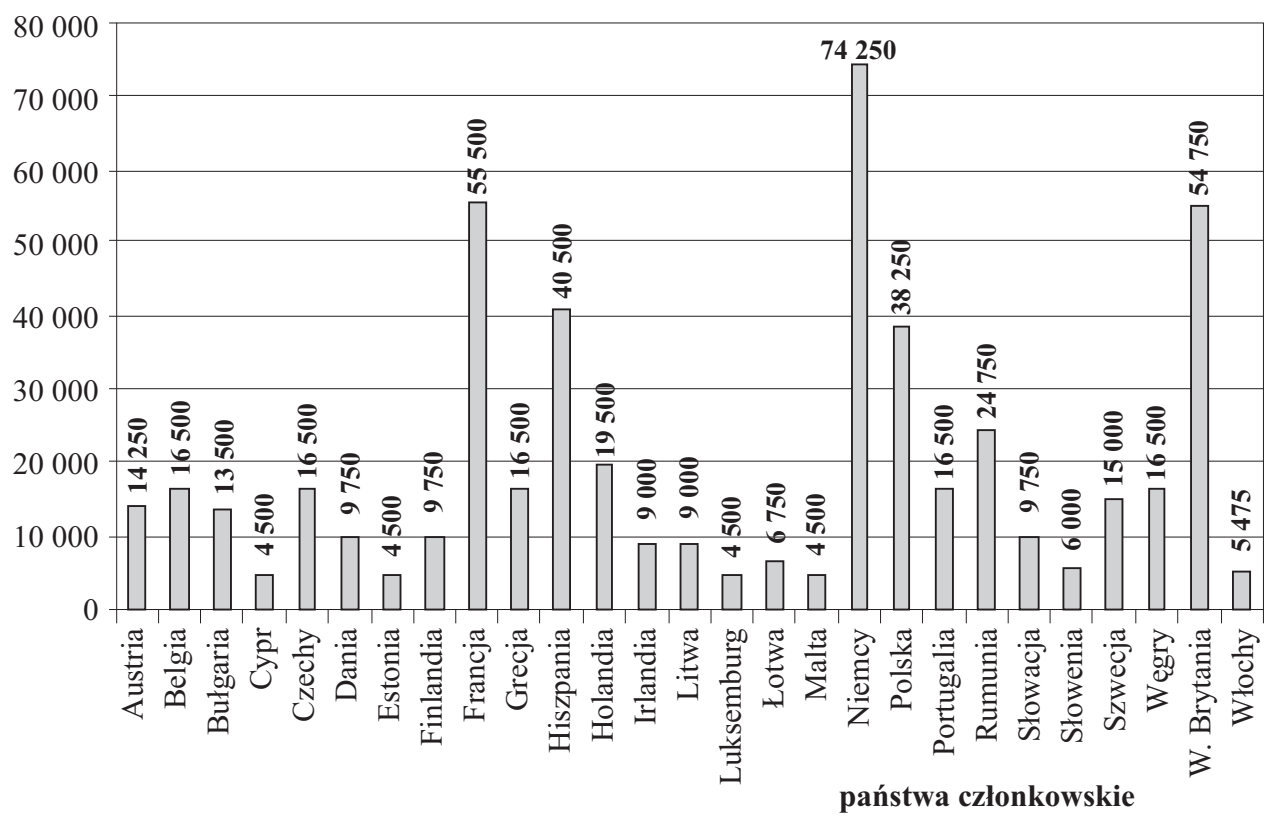

Źródło: Opracowanie własne na podstawie danych ze strony: Europejska inicjatywa obywatelska, Komisja Europejska, http://ec.europa.eu/citizens-initiative/public/basic-facts, 15.10.2012.

towania swojej inicjatywy na forum Parlamentu Europejskiego podczas wysłuchania publicznego. Po precyzyjnym przeanalizowaniu inicjatywy, Komisja Europejska musi przyjąć oficjalne stanowisko, wyjaśnić i uzasadnić kierunek swoich działań. Komunikat Komisji musi mieć „formę oficjalnego dokumentu przyjętego przez kolegium komisarzy i opublikowanego we wszystkich językach urzędowych UE. W niektórych przypadkach Komisja może wydać jedynie wstępną opinię, a decyzję ostateczną podjąc w oparciu o kolejne analizy danej sprawy. Jeżeli w odpowiedzi na inicjatywę obywatelską Komisja zdecyduje się przedstawić wniosek w sprawie aktu prawnego, rozpoczyna się proces legislacyjny - Komisja przedkłada swój wniosek legislacyjny ustawodawcy (Parlamentowi Europejskiemu i Radzie, a w niektórych przypadkach tylko Radzie). Dopiero po zatwierdzeniu przez ustawodawcę projekt staje się aktem prawnym",33.

Obecnie na stronach internetowych Komisji Europejskiej (w dziale poświęconym europejskiej inicjatywie obywatelskie) nie ma informacji o zakończonych już inicjatywach $^{34}$. Dostępne są natomiast informacje o trwających europejskich inicjatywach obywatelskich. Od maja 2012 r. zarejestrowano więc 12 inicjatyw, których tematyka - jak widać - jest bardzo zróżnicowana.

\footnotetext{
33 Europejska inicjatywa obywatelska. Przewodnik, Komisja Europejska, Luksemburg 2011, s. 26.

34 Zakończone inicjatywy, Komisja Europejska, http://ec.europa.eu/citizens-initiative/public/initiatives/finalised/answered, 15.10.2012.
} 
Trwające inicjatywy - stan na 1 listopada 2012 r.

\begin{tabular}{|l|c|c||}
\hline \multicolumn{1}{|c|}{ Tytul } & Data rejestracji & $\begin{array}{c}\text { Termin gromadze- } \\
\text { nia deklaracji }\end{array}$ \\
\hline European Initiative for Media Pluralism & 5.10 .2012 & 5.10 .2013 \\
\hline End Ecocide in Europe: A Citizens' Initiative to give the Earth Rights & 1.10 .2012 & 1.10 .2013 \\
\hline $\begin{array}{l}\text { Central public online collection platform for the European Citizen } \\
\text { Initiative }\end{array}$ & 27.08 .2012 & 26.08 .2013 \\
\hline Zawieszenie Pakietu Klimatyczno-Energetycznego UE & 8.08 .2012 & 7.08 .2013 \\
\hline Pour une gestion responsable des déchets, contre les incinérateurs & 16.07 .2012 & 15.07 .2013 \\
\hline High Quality European Education for All & 16.07 .2012 & 15.07 .2013 \\
\hline Stop vivisection & 22.06 .2012 & 21.06 .2013 \\
\hline Let me vote & 11.05 .2012 & 10.05 .2013 \\
\hline Jeden z nas & 11.05 .2012 & 10.05 .2013 \\
\hline $\begin{array}{l}\text { Dostęp do wody i kanalizacji jest prawem człowieka! Woda jest do- } \\
\text { brem publicznym, nie towarem! }\end{array}$ & 10.05 .2012 & 9.05 .2013 \\
\hline Single Communication Tariff Act & 10.05 .2012 & 9.05 .2013 \\
\hline Fraternité 2020 - Mobilność. Postęp. Europa. & 9.05 .2012 & 8.05 .2013 \\
\hline
\end{tabular}

Źródło: Trwajace inicjatywy, Komisja Europejska, http://ec.europa.eu/citizens-initiative/public/initiatives/ongoing, 1.11.2012.

Z racji że nie zakończono jeszcze procedury ani jednej europejskiej inicjatywy europejskiej, trudno jest formułować wnioski na ten temat. Analiza przedmiotów inicjatyw z tabeli 3. pozwala przypuszczać, że traktaty unijne o kluczowym dla UE znaczeniu czy reformy $w$ ramach UE nie będą przedmiotem europejskich inicjatyw obywatelskich. Niewątpliwym jednak jest, iż inicjatywa może być ważnym „obywatelskim" narzędziem demokracji bezpośredniej, które może być wykorzystywane przy mniej popularnych problemach dotykających społeczeństwo europejskie.

\section{Podsumowanie}

Demokracja bezpośrednia stanowi istotną formę sprawowania władzy uzupełniającą demokrację przedstawicielską. Bezpośrednie instytucje demokratyczne - przede wszystkim referendum ogólnonarodowe - wielokrotnie wykorzystywane były jako narządzie podejmowania decyzji związanych z procesami integracyjnymi w Europie. Na uwagę zasługuje imponująca liczba referendów w sprawie integracji - 53 głosowania w przeciągu 40 lat. Wydaje się, że żadna sprawa na świecie nie była przedmiotem tak wielu głosowań powszechnych w tak dużej liczbie państw - przypomnieć należy, iż 25 państw głosowało nad integracją.

Dodać warto, iż procesy integracji w Europie przyczyniły się do wykształcenia nowego typu głosowania - referendum akcesyjnego. Dziś praktycznie każdemu rozszerzeniu towarzyszy takie głosowanie. Istotną rolę odgrywają również referenda ,pogłębiające”, czyli te których przedmiotem są traktaty lub inne regulacje, przekładające się na pogłębienie stosunków między państwami członkowskimi Unii Europejskiej. 
Oprócz instytucji referendum narodowego - rozstrzygającego kwestie ponadnarodowe, w wachlarzu narzędzi unijnych jest również inna instytucja demokracji bezpośredniej - inicjatywa europejska o charakterze transnarodowym. To narzędzie - mimo iż relatywnie krótko stosowane (tabela 3), może mieć widoczny wpływ na proces jednoczenia się Europy w tym sensie, że dzięki propagowaniu spraw poddawanych procedurze inicjatywy obywatele UE mogą mieć większą szansę na poznanie swoich problemów i możliwość wspólnego ich rozwiązywania. Stworzenie takiej wspólnej platformy porozumienia ma szansę dać obywatelom możliwość zwrócenia uwagi zarówno władz unijnych, jak i państwowych na problemy, z jakimi borykają się obywatele UE. Warto również nadmienić, iż inicjatywa europejska - w przeciwieństwie do tzw. referendów unijnych - jest usankcjonowaną prawnie instytucją o charakterze europejskim, której przedmiotem mogą być kwestie wyłącznie europejskie (gdyby to były kwestie narodowe - trudno byłoby zebrać milion podpisów z 7 różnych państw członkowskich). W przypadku referendum prawidłowość jest nieco inna - narodowe głosowanie ma moc rozstrzygająca w kwestiach o charakterze ponadpaństwowym. Wydaje się, iż mimo uregulowania europejskiej inicjatywy obywatelskiej w prawie UE, narzędzie to wykorzystywane będzie raczej w sprawach o mniejszym znaczeniu dla funkcjonowania Unii. W zagadnieniach kluczowych - jeśli społeczność europejska będzie angażowana w proces decyzyjny - to narzędziem, za pośrednictwem którego będą podejmowane decyzje będzie referendum narodowe. Głosowanie to będzie jedną z form decydowania o pogłębianiu i poszerzeniu procesu integracji w Europie.

\section{Summary \\ Institutions of direct democracy in the process of European integration: from nationwide referendum to European civic initiative}

The idea of civic participation in national decision-making processes is an important part of European history. By means of implementing the principle of the sovereignty of nations, those eligible to vote are able to express their will through the institutions of direct democracy and representative democracy. The instruments of direct democracy are an extremely interesting research subject - not only due to the fact that the number of votes on European integration has been very high (especially in the last decade), but also because EU Member States, being aware of the importance of citizen involvement in the process of integration in Europe, established the institution of the European citizens' initiative. Using this instrument, European citizens can impact the politics of the EU. The purpose of this text is to answer the question of the role of direct democracy and its tools in the process of European integration, as well as of the prospects for the use of direct forms of governance in the process of deepening and widening integration in Europe. 